\title{
Antimicrobial Activity of Some 1,3,4-Thiadiazole Metal Complexes
}

\author{
Kadhim K. Ghudhaib*, Shaimaa R. Bakir* and Ekbal R. Hanna** \\ * Department of Chemistry, College of Science for Women, Baghdad University, Baghdad-Iraq. \\ ** Department of Biotechnology, College of Science, Baghdad University, Baghdad-Iraq.
}

\begin{abstract}
Biological activities of $\mathrm{Cu}$ (II), Pt (IV), Zn (II) and V (IV) metal complexes with 1, 3, 4 thiadiazole derivatives towards pathogenic bacteria (Staph. aureus, Bacillus cereus, Pseudomonas aerogenosa and Escherichia coli) and the fungus Candida albicans were studied. The investigation was conducted using plate agar method. Sulfadiazine was used as standard drug in this study. The results were referred to that the biological activities of the studied compounds are more effective than sulfadiazine. The minimum effective dose of the studied compounds against of the named bacteria was $50 \mu \mathrm{g} / \mathrm{ml}$, while the minimum effective dose of sulfadiazine was $100 \mu \mathrm{g} / \mathrm{ml}$. Moreover, Candida albicans was affected by all the studied compounds at $50 \mu \mathrm{g} / \mathrm{ml}$, but there is no significant effect of sulfadiazine toward Candida albicans even at the highest dose, $200 \mu \mathrm{g} / \mathrm{ml}$.
\end{abstract}

Keyword: biological activity, thiadiazole derivative, thiadiazole complexes, sulfadiazine.

\section{Introduction}

Thiadiazoles have been of a great interest as antitumor compounds for several years $[1,2]$. Studies show that the fused derivatives of triazole and thia-diazole have various biological activities such as anti-bacterial, antifungal, antiviral, antitumor, and antiinflammatory activities [3-6]. In more recent study, a series of 3, 6 disubstituted 1,2,4triazole and 1,3,4- thiadiazole were prepared and estimated in their cytotoxicity against breast and ovarian human cell lines and other biological actvities [7-12].

The degree of toxicity for some new 1,3, 4thiadiazole and 1, 2, 4- triazole derivatives was established and the potential antiinflammatory activity for these compounds was also investigated [13]. Thiadiazole derivatives are well known to have a number of biological and pharmacological activities. Significant antimicrobial activities were observed for members of thiadiazole derivatives, which were prepared by incorporation of fluorobenzothiazole with 1,3,4 - thia-diazole derivatives [14].

The improvement in the method-logical study of heterocyclic compounds leads to the progress in synthesis of such compounds with high biological activity. It was reported that many thiadiazole and triazole derivatives have biological activity, with their antibacterial [1517] and antifungal [18-19] action being notable. Recently researches were established an analgesic [20] and anti-inflammatory activity [21-22] for these heterocycles.

Asma and coworkers [23] were synthesized 2-N-arylimino -2, 3- dihydro 1,3,4- thiadiazole. A high Antimicrobial activity was found for the prepared compounds using the diffusion agar technique. In another study, various biological activities like antiinflammatory, antidiabetic and antifungal activities of some thaidiazole derivatives were evaluated [24].

In another study, in vitro antibacterial and antifungal activity of sulfonamides and some of their metal complexes were screened against different types pathogenic bacteria and fungi. The results of this study were confirmed that the activity of complexes was more effective than uncomplexed derivative [25]. Mihai Barbuio and coworkers were synthesized and studied the biological activity for some metal complexes of 5-(2- amino ethyl)-2-amino -1,3,4-thiadiazole, the prepared complexes showed in vitro antifungal activity against Aspergillus and Candida spp. [26]. Zn (II) and $\mathrm{Ag}$ (I) complexes of aminobenzolamide(5- sulfanilylamido -1,3,4- nthiadiazole -2sulfonamide) were evaluated for their antifungal activity. The prepared complexes act as effective agents against several Aspergillus and Candida spp. in comparison with their ligand. The mechanism of antifungal activity for these complexes was suggested that the complexes act as inhibitors of 
phosphomannose isomerase, a key enzyme in the biosynthesis of yeast cell walls [27].

Thiadiazole complexes with Co (II), $\mathrm{Cu}$ (II), Ni (II), and $\mathrm{Zn}$ (II) were screened for antibacterial activity against Escherichia coli, Staphylococcus aureus and pseudomonas aeruginosa. Anti-bacterial activity of thiadiazole derivative increased upon complexation in comparison to uncomplexed derivative against the tested bacterial species [28].

The aim of this work is to evaluate the biological activity of some thiadiazole metal complexes against selective of pathogenic bacteria and fungi. Sulfa-diazine was used as standard drug in this study.

The suggested structural formulas, scientific names and abbreviations of the tested compounds were written as shown in Fig.(1).

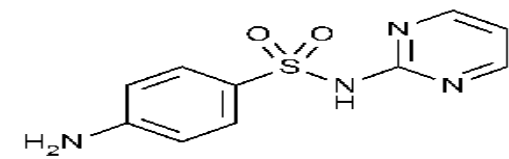

(S.D)

(1)

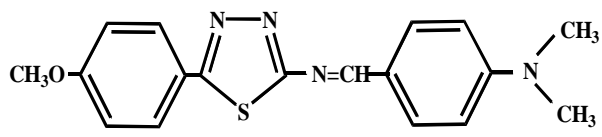

$\left(\mathrm{L}_{\mathrm{A}}\right) \quad(2)$

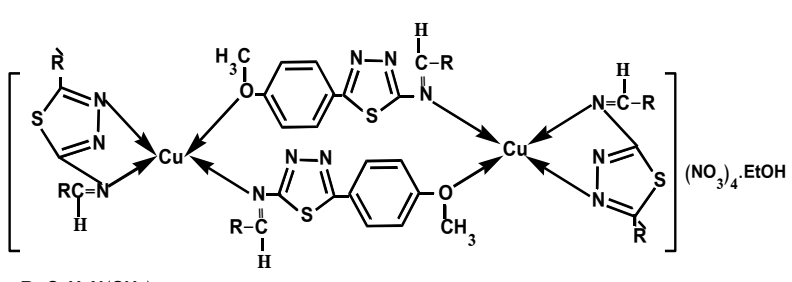

$\mathrm{R}=\mathrm{C}_{6} \mathrm{H}_{5} \mathrm{~N}\left(\mathrm{CH}_{3}\right)_{2}$

'े= $\mathrm{C}_{6} \mathrm{H}_{5} \mathrm{OCH}_{3}$

$\mathrm{Cu}\left(\mathrm{L}_{\mathrm{A}}\right)$

(3)

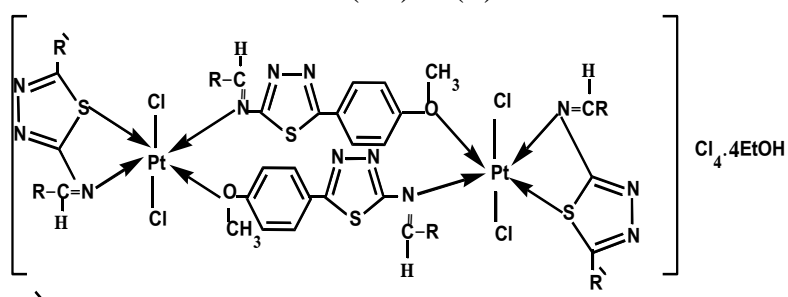

$\grave{\mathrm{R}}=\mathrm{C}_{6} \mathrm{H}_{5} \mathrm{OCH}_{3}$

$\mathrm{R}=\mathrm{C}_{6} \mathrm{H}_{5} \mathrm{~N}\left(\mathrm{CH}_{3}\right)_{2}$

$\operatorname{Pt}\left(\mathrm{L}_{\mathrm{A}}\right)$

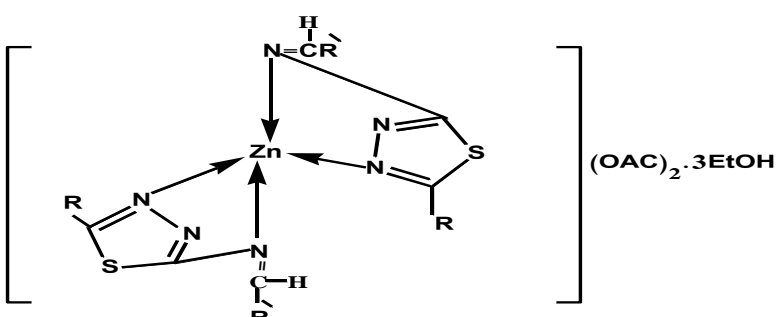

$\mathrm{R}=\mathrm{C}_{6} \mathrm{H}_{5}{ }^{\prime}$

$\hat{R}=\mathrm{C}_{6} \mathrm{H}_{5} \mathrm{~N}\left(\mathrm{CH}_{3}\right)_{2}$

$\mathrm{Zn}\left(\mathrm{L}_{\mathrm{B}}\right)$

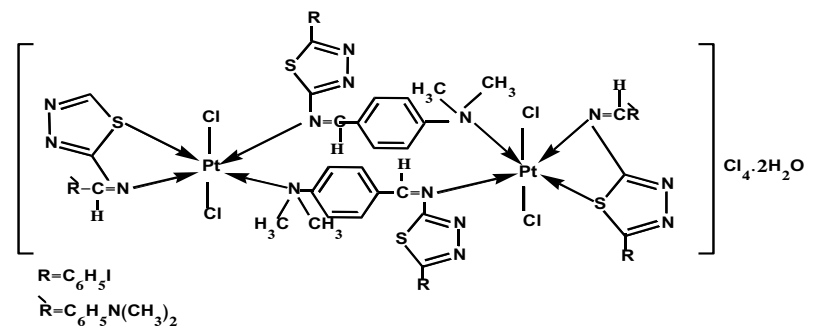

$\mathrm{Pt}\left(\mathrm{L}_{\mathrm{B}}\right) \quad$ (6)

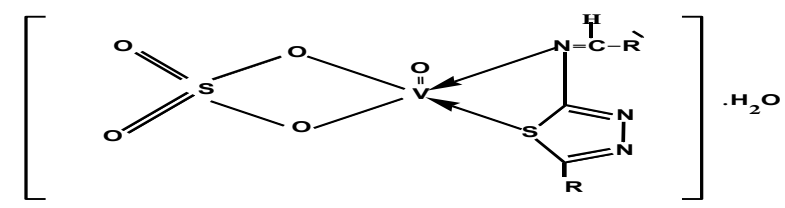

$\mathrm{R}-\mathrm{C}_{\mathbf{G}^{-}} \mathbf{H}^{\mathbf{1}}$

$\mathrm{R}-\mathrm{C}_{6} \mathrm{H}_{5} \mathrm{~N}^{\left(\mathrm{CH}_{3}\right)_{2}}$

$\mathrm{V}\left(\mathrm{L}_{\mathrm{B}}\right)$

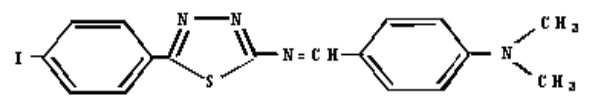

$\mathrm{L}_{\mathrm{B}} \quad(8)$

Fig. (1) The structural formulas and scientific names of the studied compounds 29,31 . 


\begin{tabular}{|c|c|c|}
\hline No & Scientific name & abbreviation \\
\hline$\overline{1}$ & Standard drug (sulfadiazine) & S.D \\
\hline 2 & \begin{tabular}{|llllll}
$\begin{array}{l}2-\mathrm{N} \\
\text { thiadiazole }\end{array}$ & $(4-\mathrm{N}, \mathrm{N}-$ dimethylenzyliden-5-(p-methoxy & phenyl) & -1, & 3, & $4-$ \\
\end{tabular} & $\mathbf{L}_{\mathbf{A}}$ \\
\hline 3 & $\begin{array}{l}\text { Bis } \mu \text {-(2-N (4-N, N-dimethyl benzyliden-5-(p- methoxy phenyl)-1, 3, 4- } \\
\text { thia diazole bis } \\
(2-\mathrm{N}(4-\mathrm{N}, \mathrm{N} \text { dimethyl benzyliden }-5-(\mathrm{p}-\text { methoxy phenyl) }-1,3,4- \\
\text { thiadiazole } \\
\text { dicupper (II) nitrate, ethanol }\end{array}$ & $\mathrm{Cu}\left(\mathbf{L}_{\mathbf{A}}\right)$ \\
\hline 4 & $\begin{array}{l}\text { Bis } \mu \text {-(2-N (4-N, N-dimethyl benzyliden-5-(p-methoxy phenyl)-1 } \\
\text { 3,4thiodiazole } \\
\text { bis(dichloro(2-N(4-N,N-dimethyl } \\
\text { 1,3,4- } \\
\text { thiodiazole diplatinum (IV) chloride .ethanol }\end{array}$ & $\operatorname{Pt}\left(\mathbf{L}_{\mathbf{A}}\right)$ \\
\hline 5 & $\begin{array}{l}\text { Bis(2-N(4-N,Ndimethylbenzyliden-5-(p-Iodophenyl)- } \\
\text { 1,3,4thiodiazole)Zinc (II).acetate.ethanol }\end{array}$ & $\mathbf{Z n}\left(\mathbf{L}_{\mathbf{B}}\right)$ \\
\hline 6 & $\begin{array}{l}\text { Bis } \mu-(2-N \quad(4-N, \quad N d i m e t h y l b e n z y l i d e n-5-(p-I o d o p h e n y l)-1,3,4 \\
\text { thiodiazole bis } \\
\text { (dichloro }(2-\mathrm{N}(4-\mathrm{N}, \mathrm{N} \text { - dimethyl benzyliden-5-(p-Iodophenyl)-1, 3, 4- } \\
\text { thiodiazole } \\
\text { diplatinum (IV) chloride.water }\end{array}$ & $\mathbf{P t}\left(\mathbf{L}_{\mathbf{B}}\right)$ \\
\hline 7 & $\begin{array}{|lll|}\text { Sulphato(2-N(4-N,N-dimethyl } & \text { benzyliden-5-(p-Iodo } & \text { phenyl)- } \\
\text { 1,3,4thiodiazole Vindyl(IV).water } & & \\
\end{array}$ & $\mathbf{V}\left(\mathbf{L}_{\mathbf{B}}\right)$ \\
\hline 8 & 2-N(4-N,Ndimethylbenzyliden-5-(p-Iodophenyl)- 1,3,4thiodiazole & $\mathbf{L}_{\mathbf{B}} *$ \\
\hline
\end{tabular}

* The biological activity of $\mathrm{L}_{\mathrm{B}}$ (ligand $\mathrm{B}$ ) was not evaluated in this study.

\section{Experimental}

1, 3, 4 - thiadiazole derivatives, $\left(\mathrm{L}_{\mathrm{A}} \& \mathrm{~L}_{\mathrm{B}}\right)$ and their complexes with $\mathrm{Cu}$ (II), $\mathrm{Zn}$ (II), $\mathrm{Pt}$ (IV) and V (IV) were prepared, purified and characterized as reported in elsewhere [29]. Sulfadiazine of the highest available quality was purchased from Merck Company.

Staphylococcus aureus, Bacillus cereus (gram-positive), Pseudomonas and Escherichia coli (gram- negative) bacteria, and Candida albicans were obtained from the Biotechnology Department, Collage of Science, University of Baghdad. The antimicrobial activity was achieved by plate agar method [30]. Microorganisms were cultured aerobically at $37 \mathrm{C}$ for 24 hours in nutrient agar medium. The plates containing agar medium were inoculated by microorganism suspensions, which are spreading on the surface. Each sample $(100 \mu 1)$ was placed in a hole ( $3 \mathrm{~mm}$ depth, $4 \mathrm{~mm}$ diameter) made in the agar layer. Under the same conditions, solutions of sulfadiazine were used as standard. The diameter of inhibition zones was measured using a ruler with an accuracy of 0.5 $\mathrm{mm}$. A control using only inoculation by solvent (DMSO) was also carried out.

\section{Results and Discussion}

It was reported that the active concentration $100 \mu \mathrm{g} / \mathrm{ml}$ and the upper allowed concentration for sulfadiazine drug was $150 \mu \mathrm{g} / \mathrm{ml}$ [31]. Accordingly, four different concentrations of the studied compounds were prepared, $200 \mu \mathrm{g} / \mathrm{ml}\left(\mathrm{C}_{1}\right)$, $150 \mu \mathrm{g} / \mathrm{ml}\left(\mathrm{C}_{2}\right), 100 \mu \mathrm{g} / \mathrm{ml}\left(\mathrm{C}_{3}\right)$ and $50 \mu \mathrm{g} / \mathrm{ml}$ $\left(\mathrm{C}_{4}\right)$.

It can be seen from Tables (1-4) that sulfadiazine was not effective toward all types of the studied bacteria at concentration lower than100 $\mu \mathrm{g} / \mathrm{ml}$, on the other hand, the biological activity of the 1,3,4-thiadiazole and its complexes against the studied bacteria was detected even at the lower concentration, $50 \mu \mathrm{g} / \mathrm{ml}$. 
The results also showed that the $\mathrm{Pt}\left(\mathrm{L}_{\mathrm{B}}\right)$ complex was appeared high activity against to Staph. aureus, Bacillus cereus and Escherichia coli in comparison to other compounds as shown in Tables (1-3). Both $\mathrm{Cu}\left(\mathrm{L}_{\mathrm{A}}\right)$ and $\mathrm{V}\left(\mathrm{L}_{\mathrm{B}}\right)$ complexes were found to be the most active compounds against to Pseudomonas as shown in Table (4).

Table (5) showed that there is no significant effect of sulfadiazine against the fungus Candida albicans even at the highest dose $200 \mu \mathrm{g} / \mathrm{ml}$. However, the biological activity of the studied compounds against Candida albicans was detected at the lowest dose $50 \mu \mathrm{g} / \mathrm{ml}$. The biological activity of $\mathrm{Pt}\left(\mathrm{L}_{\mathrm{B}}\right)$ complex was recorded as the highest one against this type of fungus.

Antibacterial and antifungal activities for some thaidiazoles were evaluated In vitro. The variations in their activities were elucidated on the base of the different substituted functional groups [32]. Antibacterial and antifungal activities were reported for another series of thiadiazole compounds. They exhibited moderate to good antibacterial antifungal activity [33]. More recently, a study reported the successful synthesis of fluorinated azoles, which was described as novel classes of microbial agents [34].

The differences in biological activity towards certain types of microorganism between thiadiazole derivative and its complexes may be attributed to synergetic effect that occurred between metal ion and ligand. Therefore, metal ion may be reduce or enhance the biological activity of the prepared compound. However, such behavior is affected by types of bacteria $[26,35]$.

\section{Conclusion}

The biological activity of thiadiazole derivative was increased when it coordinated with metal ion to form metal complex.

Thiadiazoles are considered to be among active antibacterial and antifungal agents. Generally, the basic of anti-bacterial agents action can be attributed to one or more of the following factors: inhibition of essential metallic reactions within the cytoplasm of microorganism, inhibition of cell wall synthesis and inhibition of RNA synthesis which involve the inhibition of replication of DNA. We concluded that the behavior of our compounds in this work were bactericidal not bacteriostatic.

Table (1)

Biological activity of the studied compounds against Staph. Aureus.

\begin{tabular}{||l||l|l||l||l|l||l|}
\hline No & Compounds & C1 & C2 & C3 & C4 & Control \\
\hline \hline 1 & S.D. & $15 \mathrm{~mm}$ & $12 \mathrm{~mm}$ & $10 \mathrm{~mm}$ & -- & -- \\
\hline \hline 2 & $\mathrm{~L}_{\mathrm{A}}$ & 20 & 15 & 13 & 10 & -- \\
\hline \hline 3 & $\mathrm{Cu}\left(\mathrm{L}_{\mathrm{A}}\right)$ & 21 & 15 & 12 & 10 & -- \\
\hline \hline 4 & $\mathrm{Pt}\left(\mathrm{L}_{\mathrm{A}}\right)$ & 17 & 15 & 11 & 10 & -- \\
\hline 5 & $\mathrm{Zn}\left(\mathrm{L}_{\mathrm{B}}\right)$ & 15 & 11 & 10 & 9 & -- \\
\hline \hline 6 & $\mathrm{Pt}\left(\mathrm{L}_{\mathrm{B}}\right)$ & 23 & 17 & 15 & 12 & -- \\
\hline 7 & $\mathrm{~V}\left(\mathrm{~L}_{\mathrm{B}}\right)$ & 11 & 10 & 10 & 10 & -- \\
\hline \hline
\end{tabular}

(--) Effective killing area is not significant.

$* *(\mathrm{~mm})=$ Inhibition zone diameter

Table (2)

Biological activity of the studied compounds against Bacillus cerus.

\begin{tabular}{||l||l|l||l||l||l||l|}
\hline No & Compounds & $\boldsymbol{C 1}$ & $\boldsymbol{C 2}$ & $\boldsymbol{C 3}$ & $\boldsymbol{C 4}$ & Control \\
\hline \hline 1 & S.D. & $17 \mathrm{~mm}$ & $14 \mathrm{~mm}$ & $12 \mathrm{~mm}$ & -- & -- \\
\hline \hline 2 & $\mathrm{~L}_{\mathrm{A}}$ & 19 & 13 & 11 & 10 & -- \\
\hline 3 & $\mathrm{Cu}\left(\mathrm{L}_{\mathrm{A}}\right)$ & 25 & 20 & 15 & 12 & -- \\
\hline 4 & $\mathrm{Pt}\left(\mathrm{L}_{\mathrm{A}}\right)$ & 20 & 18 & 16 & 15 & -- \\
\hline 5 & $\mathrm{Zn}\left(\mathrm{L}_{\mathrm{B}}\right)$ & 22 & 19 & 15 & 10 & -- \\
\hline
\end{tabular}




\begin{tabular}{|l||l||l||l||l||l||l||}
\hline 6 & $\mathrm{Pt}\left(\mathrm{L}_{\mathrm{B}}\right)$ & 22 & 18 & 18 & 17 & -- \\
\hline 7 & $\mathrm{~V}\left(\mathrm{~L}_{\mathrm{B}}\right)$ & 15 & 13 & 10 & 10 & -- \\
\hline
\end{tabular}

Table (3)

Biological activity of the studied compounds against Escherichia coli.

\begin{tabular}{||l|l|l|l|l|l|l||}
\hline No & Compounds & C1 & C2 & C3 & C4 & Control \\
\hline \hline 1 & S.D. & $20 \mathrm{~mm}$ & $17 \mathrm{~mm}$ & $15 \mathrm{~mm}$ & -- & -- \\
\hline 2 & $\mathrm{~L}_{\mathrm{A}}$ & 20 & 15 & 13 & 12 & -- \\
\hline 3 & $\mathrm{Cu}\left(\mathrm{L}_{\mathrm{A}}\right)$ & 20 & 19 & 15 & 14 & -- \\
\hline 4 & $\mathrm{Pt}\left(\mathrm{L}_{\mathrm{A}}\right)$ & 22 & 19 & 18 & 14 & -- \\
\hline 5 & $\mathrm{Zn}\left(\mathrm{L}_{\mathrm{B}}\right)$ & 20 & 20 & 17 & 16 & -- \\
\hline 6 & $\mathrm{Pt}\left(\mathrm{L}_{\mathrm{B}}\right)$ & 20 & 20 & 20 & 19 & -- \\
\hline 7 & $\mathrm{~V}\left(\mathrm{~L}_{\mathrm{B}}\right)$ & 21 & 20 & 20 & 15 & -- \\
\hline \hline
\end{tabular}

Table (4)

Biological activity of the studied compounds against Pseudomonas aerogenosa.

\begin{tabular}{|l||l||l||l||l|l||l||}
\hline No & Compounds & C1 & C2 & C3 & C4 & Control \\
\hline \hline 1 & S.D. & $18 \mathrm{~mm}$ & $15 \mathrm{~mm}$ & $13 \mathrm{~mm}$ & -- & -- \\
\hline \hline 2 & $\mathrm{~L}_{\mathrm{A}}$ & 20 & 15 & 13 & 10 & -- \\
\hline \hline 3 & $\mathrm{Cu}\left(\mathrm{L}_{\mathrm{A}}\right)$ & 17 & 16 & 15 & 15 & -- \\
\hline 4 & $\mathrm{Pt}\left(\mathrm{L}_{\mathrm{A}}\right)$ & 22 & 18 & 15 & 10 & -- \\
\hline 5 & $\mathrm{Zn}\left(\mathrm{L}_{\mathrm{B}}\right)$ & 18 & 17 & 15 & 14 & -- \\
\hline \hline 6 & $\mathrm{Pt}\left(\mathrm{L}_{\mathrm{B}}\right)$ & 19 & 17 & 16 & 14 & -- \\
\hline 7 & $\mathrm{~V}\left(\mathrm{~L}_{\mathrm{B}}\right)$ & 23 & 20 & 18 & 15 & -- \\
\hline \hline
\end{tabular}

Table (5)

Biological activity of the studied compounds against Candida albicans.

\begin{tabular}{|l||l|l||l|l||l||l||}
\hline \hline No & Compounds & C1 & C2 & C3 & C4 & Control \\
\hline \hline 1 & S.D. & $--\mathrm{mm}$ & $--\mathrm{mm}$ & $--\mathrm{mm}$ & $--\mathrm{mm}$ & -- \\
\hline 2 & $\mathrm{~L}_{\mathrm{A}}$ & 15 & 14 & 12 & 11 & -- \\
\hline \hline 3 & $\mathrm{Cu}\left(\mathrm{L}_{\mathrm{A}}\right)$ & 20 & 19 & 18 & 15 & -- \\
\hline 4 & $\mathrm{Pt}\left(\mathrm{L}_{\mathrm{A}}\right)$ & 18 & 17 & 16 & 16 & -- \\
\hline 5 & $\mathrm{Zn}\left(\mathrm{L}_{\mathrm{B}}\right)$ & 35 & 30 & 18 & 16 & -- \\
\hline 6 & $\mathrm{Pt}\left(\mathrm{L}_{\mathrm{B}}\right)$ & 25 & 23 & 20 & 18 & -- \\
\hline 7 & $\mathrm{~V}\left(\mathrm{~L}_{\mathrm{B}}\right)$ & 30 & 21 & 21 & 14 & -- \\
\hline
\end{tabular}

\section{References}

[1] Hirpara, S.B; Parikh, K. A; Merja, B. C. and Parekh, H. H. 2- Methoxy-5-methyl phenylthiosemicarbazide: A versa-tile molecule for the synthesis of thia-diazoles and imidazolinones possessing multiple biological activities. Indian Journal of Chemistry. 2003.42 B: 1172- 1175.

[2] Azam, M.A; Kumar, B.R;Shalini, S; Suresh, B; Reddy, T.K. and Reddy, C.D. Synthesis and biological screening of 5\{[(4,6-disubstituted pyrimidine-2-yl) thio] methyl - N-phenyl 1,3,4- thiadiazol -2amines. Indian Journal of Pharma-ceutical Sciences. 2008. 70 (5):672-677.

[3] Karabasanagouda, T; Adhikari, A.V. and Suchethasettey, N. Synthesis and antimicrobial activities of some novel 1,2,4triazolo[3,4-b]-1,3,4- thiadiazoles and 1,2,4- triazolo [3,4-b] -1,3,4-thia-diazines carrying thioalkyl and sulphonyl phenoxy moieties. European Journal of Medicinal Chemistry. 2007.42 (4): 521-529. 
[4] Demirbas, N; Demirbas, A. and Javed, S.A. Synthesis and antimicrobial activities of some new $[1,2,4]$ triazolo[3,4- $b][1,3,4]$ thiadiazoles and $[1,2,4]$ triazolo $[3,4-b]$ $[1,3,4]$ thiadiazines. Arkivoc. 2005. 1: 75-91.

[5] Al-Masoudi, N.A. and Al-Soud, Y.A. New Sulfonamide and Carboxamide Derivatives of Acyclic C-Nucleosides of Triazolothiadiazole Backbones and The Thiadiazine Analogues. Synthesis and anti-HIV activity. Part 2. Nucleosides, Nucleotides and Nucleic Acids. 2008. 27(9): 1034 - 1044.

[6] Amir, M; Harish, K. and Javed, S.A. Condensed bridgehead nitrogen heterocyclic system: Synthesis and pharmacological activities of 1, 2, 4-triazolo-[3, 4b]-1,3,4-thiadiazole derivatives of ibuprofen and biphenyl-4-yloxy acetic acid. European Journal of Medicinal Chemistry. 2008. 43 (10) :2056-2066.

[7] Kaliappan, I. and Parthiban, V. Facile synthesis and cytotoxic activity of 3,6disubstituted 1, 2, 4-triazolo [3, 4, b] 1, 3, 4- thiadiazoles. European Journal of Chemistry. 2010.1 (1):50-53.

[8] Neelottama Kushwaha, Swatantra K. S. Kushwaha and A.K. Rai. Biological activities of thiadiazole derivatives: A Review. International journal of chem. tech. research, 2012. vol. 4 (2), p 517-53.

[9] Shakir Mahmood Alwan. Synthesis and preliminary antimicrobial activities of new arylidene -amino -1,3,4- thiadia-zole (thio/ dithio) acetamido cephalo-sporanic Acids, Molecules. 2012. Vol 17, p 1025-1038.

[10] Tanveer ahmed, Arvend kumar Singh, Nupur Jaiswal and deepika Singh. Synthesis and pharmacological activity of 1,3,4thaidiazole derive-ative: a review. International journal of pharmacy, 2012. Vol. 3(3) p70-82.

[11] Nadeem Siddiqui, Satish Kumar Arya, Waquar Ahsanb and Bishmillah Azad. Diverse biological activities of Thiazoles: A Retrospect. International Journal of Drug Development \& Research. 2011. Vol. 3(4). p 55-67.

[12] K. Liaras, A. Geronikaki, J. Glamoc Lija, A. C Iric and M. Sokovic. Thiazole-based chalcones as potent antimicrobial agents, Synthesis and biological evaluation.
Bioorganic \& Medicinal Chemistry. 2011.Vol. 19, p.3135-3140.

[13] Mihaela, M. Valeriu, S; Leuta, P; Marcel P. and Jacques D. Synthesis and biological activity of some new 1, 3, 4- thiadiazole and 1,2,4- triazole compounds containing a phenylalanine moiety. Molecules. 2009. Vol.14:2621-2631.

[14] Vedavathi M, Somashear B, Sreenivasa M, and Jayachandran E. Synthesis, characterization and anti-microbial activity of fluorobenzothiazole incorperated with 1,3,4- thiadiazole. Journal of Pharmaceuticl Sciences and Research. 2010. 2(1):53-63.

[15] Varvarason, A; TantiliKakoulidou, A; Siatra Papastasikoudi, T. And Tiligada E.. Synthesis and biological evaluation of indole containing derivatives of thiosemicarbazide and their cyclic 1, 2, 4triazole and 1, 3, 4-thiadiazole analogs. Arzneim Forsch. 2000. Vol. 50: 48-54.

[16] Serivastava, S.K; Verma, S. and Serivastava, S.D. Synthesis, character-ization and biological activity activity of 1,3 thiazolidin-4-one derivatives of 2-mercapto5-methyl -1, 3, 4- thaidiazole. Journal of Chemical and Pharmaceutical Recearch. 2010. Vol. 2 (5):270-276.

[17] Pintilie, O; Profire, L; Sunel, V; Popa, M. and Pui, A. Synthesis and antimicrobial activity of some new 1, 3, 4-thiadiazole and 1, 2, 4-triazole compounds having a D, L-methionine moiety. Molecules. 2007. Vol. 12: 103-113.

[18] Zan,X.I; Lai,L.H; Jin,G.Y. and Zhong, Z.X. 2002. Synthesis and fungicide activity of 1, 3, 4-oxadiazoles and 1, 3, 4thiadiazoles. Journal of Agricultural and Food Chemistry. 50: 3757-3760.

[19] Chem, H; Li, Z. and Han, Y. 2000. Synthesis and fungicidal activity against Rhizoctonia solani of 2-alkyl (alkylthio) - 5 -pyrazolyl- 1, 3, 4 - oxadiazoles (thiadiazoles). Journal of Agricultural and Food Chemistry. 48: 5312-5315.

[20] Shenone, S; Bruno, O; Ranise, A; Bondavalli, W; Falcone, G; Giordano, L. and Vitelli, M..3-Arylsulphonyl-5-arylamino-1, 3, 4-thiadiazol-2(3H) ones as antiinflammatory and analgesic agents 
Bioorganic and medicinal chemistry. 2001. Vol. 9: 2149-2153.

[21] Labanauskas, L; Kalcas V, Uderenaite, E; Gaidelis, P; Brukstus, A. and Dauksas, V. Synthesis of 3-(3, 4- dimethoxy-phenyl) 1H-1, 2, 4-triazole-5-thiol and 2-amino-5(3, 4-dimethoxyphenyl) -1, 3, 4-thiadiazole derivatives exhibiting anti-inflammatory activity. Pharmazie. 2001. Vol. 56: 617619.

[22] Palaska, E; Sahin, G; Kelincen, P; Durlu, N.T. and Altionax, G.Synthesis and antiinflammatory activity of 1-acyl thiosemicarbazides, 1, 3, 4-oxadiazoles , 1,3,4-thiadiazoles and 1, 2, 4-triazole-3thiones. Farmaco; 2002. Vol. 57(2): 101107.

[23] Asma, M; Nasser A. and Hasan, A. One step synthesis and antimicrobial activities of new substituted dihdro -1, 3,4- thiadizoles. Archives Pharmacal Research. 2006. Vol. 29(1):46-49.

[24] Shashikant, R.P; Pragact, K; Nachiket; S. D; Sunil, A. N; Deepak; S. M; Smita, K. P. and Aarti, D. Synthesis and biological evaluation of some 1, 3, and 4thiadiazoles. Journal of Chemistry and Pharmaceutical Research. 2009. Vol. 1(1):191-198.

[25] Zahid, H.C; Mahmood, H; Khalid, M.K. and Claudiu T. S. In-vitro antibacterial, antifungal, and cytotoxic properties of sulfonamide-derived Schiff's bases and their metal complexes. Journal of Enzyme Inhibition and Medicinal Chemistry. 2005. Vol. 20 (2): 183 - 188.

[26] Mihai, B; Marilena, C; Cornelia, G. and Claudiu, T.S. Synthesis and biological activity of metal complexes. Metal-Based Drugs. 1996. Vol. 3 (5): 227-232.

[27] Antonio, M; Andrea, S. and Claudiu T. S. Antifungal Activity of Ag (I) and Zn (II) Complexes of Aminobenzolamide(5Sulfanilylamido- 1,3,4 -Thiadiazole -2Sulfonamide) Derivatives. Journal of Enzyme Inhibition and Medicinal Chemistry. 2000. Vol. 15 (6):517-531.

[28] Zahid, H. C; Humayun, P; Abdul Rauf, Andrea S. and Claudiu, T.S. Antibacterial $\mathrm{Co}$ (II), $\mathrm{Cu}$ (II), $\mathrm{Ni}$ (II) and $\mathrm{Zn}$ (II) Complexes of Thiadiazole Derived Furanyl, Thiophenyl and Pyrrolyl Schiff Bases.
Journal of Enzyme Inhibition and Medicinal Chemistry. 2002. Vol. 17, (2): 117-122.

[29] Shaimaa, R.B. Synthesis, and Characterization of some new Shiff Bases and their Complexes with Selection of Elements and their Theoritical Study, M.Sc. Thesis. College of Science, Baghdad University, Baghdad, Iraq.2007. pp. 32-37.

[30] Mary, J; Geaig, A; Mechael, N; George, E; David, W.H; Albert, T.S; Tana, C.T. and Melvin, P.W.Performance standards for antibacterial susceptibility testing. West Vally. USA. 2002. pp.72.

[31] Wilson, S. and Gisvold. Text book of organic medicinal and pharmaceutical chemistry. Ninth Eddition. hppincott company, New York, 1991. pp. 91.

[32] Charalabos, C; Athina, G; Ana, C; Marina, S; Panagiotis, Z. and Maria, Z. Sulfonamide -1, 2, 4- thiadiazole derivatives as antifungal and antibacterial agents: synthesis, biological evaluation, lipophilicity, and conformational studies. Chemical and Pharmaceutical Bulletin. 2010. Vol. 58 (2):160-167.

[33] Barve, A; Joshi, A; Nema, R. K; Gehlot, S; Subhedar, N, Daniel V. and Singh, P. Synthesis, characterization, and antimicrobial activity of azol substituted derivatives. International Journal of Pharmaceutical Sciences and Drug Research. 2009. Vol. 1(3): 207-210.

[34] Sharad, S; Nilesh, S; Sandeep, S; Swapnil, B; Nilesh, N; Ganesh, M;Ranjana, J. and Bhausaheb, K.Synthesis and antimicrobial screening of some fluorinated azoles. Journal of the Korean Chemical Society. 2010. Vol. 54(1): 59-64.

[35] Rajiv, D. and Sarivastana S.K. Synthesis, characterization and microbial activity of 2(2- substituted- benzylidene -hydrazinoacetyl) - mercapto -5 -methyl - 1,3,4thiadiazole and 2-[2- \{4- substituted - aryl3-chloro -2 - oxo - azitidine \} acetylaminomercapto]- 5methyl - 1,3,4thiadiazoles. International Journal of Pharma and Bio Sciences. 2010. Vol. 1(2): 1-7. 


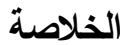

درست الفعالية الحيوية لمعقدات Cu (II) و ل Cu (II) و

Pt (IV)

عزلات مختارة من البكتريا المرضية (بكتريا المكورات

العنقودية والعصوية وزائفة القيح الازرق واشريكيا القولون)

وفطر المبيضات البيض.

اجريت الدراسة بطريقة اطباق بتري وباستخدام

السلفادايازين كعقار قياسي. اشارت النتائج الى ان الفعالية لتربية

الحيوية للمركبات المحضرة تجاه البكتريا كانت ذات ناثير

عالي في التركيز الاوطأ (50 مايكروغرام/ مل) مقارنة بعقار

السلفادايازين الذي لم يكن مؤثرا في نركيز يقل عن 100

مايكروغرام/ مل، فضلا عن تاثيرها على فطر المبيضات

البيض الذي لم يؤثر عليه السلفادايازين حتى في التركيز

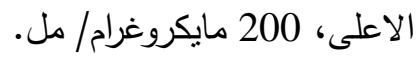

